me to continue the investigation after the first field had been marked out a spiral was obtained (Fig. 1) which was identical with that supposed to be characteristic of hysteria (Fig. 2). I expect that the reason why a spiral field of vision, which is the natural result of continued suggestion, has not been found in a larger proportion of hysterical cases showing a narrow field of vision is simply because it has not been looked for, the examiner being content when he has marked the limit of vision a single time in each direction.

Captrin J. L. M. Symns and $I$ have found in several cases of hysteria that an outward spiral was always obtained instead of an inward one if the white disc of the perimeter was moved outwards instead of inwards, as is commonly done. This proves conclusively that the ordinary inward spiral is the result of suggestion and not of fatigue.

In malingering some symptoms are produced voluntarily by the individual on his own initiative and others are produced voluntarily after being prompted by suggestions made unconsciously by the observer. The same two processes occur in hysteria, with the difference that they are involuntary, the symptoms being produced subconsciously, some by auto-suggestion and others by suggestions made by the observer. It is thus quite impossible to diagnose hysteria from malingering by a study of the symptoms alone.

$$
\text { I am, Sir, yours faithfully }
$$

Netley, Oct. 21st, 1917 ARTHUR F. HURST.

\section{THE FUTURE OF THE POOR-LAW.}

\section{To the Editor of THE LANCET.}

SrR,--It is time for those who wish to continue as Poor-law medical officers to wake up. There is a proposition which many are wanting to see acted on-viz., that the Poor-law service should become part of, and merged into, the present and future general insurance scheme. The majority (about 2 to 1 ) of the members of the Poor-law Medical Officers' Association do disapprove of any alteration. It would help if all Poor-law medical officers would send me each their opinion and wish in as few decisive words as possible. could then tabulate them and find the wish of the majority and make the conclusion known in THE LANCET and British Medieal Journal.

There is a promise of compensation for vested interests if lost by change of Act of Parliament, but the compensation is never equal to the oftice and money lost. It may be a compensation, but not an absolute quid pro quo. It is not right that those who have no personal interests should decide for those whose actual living and other details of work centre round a Poor-law appointment. It is easy to look down from a higher perch and wish to brush special departmental appointments into the general hubbub. This is just what a State service commandant would like to do. I say again that the future of the Poor-law will be influenced by the amount of resistance offered by its medical and civil officers. I am, Sir, yours faithfully,

$$
\text { A. Withers GreEN, }
$$

Honorary Secretarv, Poor-law Medical Officers' Wardrobe-place, E.C.4, Nov. 2nd, 1917.

\section{INSANE SAILORS AND SOLDIERS.}

\section{To the Editor of THE LANCET.}

SIR,-Dr. J. F. Gemmel writes with feeling on this subject in your issue of Oot. 20th. I myself have an intense admiration and deep sympathy for our insane sailors and soldiers. So much so that when the Board of Control circularised asylum committees I advised our committee to suggest just such a project as Dr. Gemmel's. The Board of Control replied that such a project was not feasible for two reasons (if I remember correctly). The first was that the mental invalids would be out of reach of their friends, and the second that the numbers affected would be too great. I have always found the Board deeply interested in the welfare of the insane.

The points for consideration seem to me to be as follows :1. To erect an asylum for these so-called "service patients" is to erect a monument to them. The public would call it the "soldiers' asylum." The stigma would remain and be magnified. The same result would follow if we kept an already-erected asylum for them. 2. Removal from War Office influence, from all reminders of war, would be bene- ficial. This can be better done as the Board of Coutrol suggests. 3. Documentary evidence, or the want of it, will not make these patients either more or less insane. And certification is protection. Certified patients are protectrd by the Board of Control. 4. From the point of view of the patients' friends the patients are best in the nearest asylum to them (and this can always be arranged under existing circumstances), and in the nearest cemetery after death. 5. Amongst my cases those patients in whom sufficient intelligence remains have preferred to go near their friends. 6. The term pauper is a misnomer. Many. I should say the majority of patients, in so-called "pauper asylums" are not paupers. Furthermore, most of them come from the same class as the majority of our sailors and soldiers. These will not feel their position as patients but merely as insane patients. 7. The allowance of $3 s .9 d$. above the maintenance rate is not all : $2 s .6 d$. is allowed for extra comforts and should be made use of. Perhaps even this is not enough, but no doubt time will tell and more may be granted.

I consider that every patient who has been in the Army or Navy honestly should be classed as a "Service patient." They did their best and broke down. All honour to them ! Much can be done for them. Where there are many special wards can be allocated to them. Special privileges can be granted to them. Special kindness can be shown to them. If the letter of $\mathrm{my}$ old colleague Dr. Gemmel encourages other superintendents to do their very best for insane sailors and soldiers it will not have been written in vain.

I am, Sir, yours faithfully, W. J. A. ERSKINE.

County Asylum, Newport, I.W., Nov. 2nd, 1917.

\section{THE VESTIBULAR TESTS AND FUNC- TIONAL DEAFNESS.}

\section{To the Editor of THE LANCET.}

SiR, - I think that if Dr. P. McBride were to carry out the vestibular tests regularly in cases of perceptive deafness their scepticism as to their general usefulness as aids in the diagnosis of functional deafness might become modified. It is now about five zears since I first drew attention to the interesting and still unexplained fact that the vestibular sense-organ seems to become impaired in harmony with the degree of severity of the cochlear disease in cases showing perceptive deafness due to organic disease. This phenomenon appears, as Dr. McBride says, even in cases of noise-deafness. On the other hand, I have shown, and I believe that the observation has been generally confirmed, that in functional nerve-deafness, whether due to hysteria or neurasthenia, the vestibular reactions are as lively as, or even more lively than, the normal.

To these broad general statements there are, no doubt, exceptions to be made, and if any of your correspondents are interested in the subject I refer them to the Proceedings of the Otological Section of the Royal Society of Medicine, and more particularly to the discussion on nystagmus (jointly with the Ophtha]mological and Neurological Sections), where I had an opportunity of expressing views on the subject which subsequent experience has not materially modified.

Nov. 6th, 1917. I am, Sir, yours faithfully References.-Proceeds. Roy. Soc. Med., Otolog. Sect., vol. iii., p. 74, vol. v., p. 18; and Juint Discussion on Nystagmus, Feb. 26th, 1914.

\section{THE SOURCE OF SPIROCH \&TES IN URINE.}

\section{To the Editor of THE LANCET.}

SIR, - As one among others who have recently been engaged with the investigation of trench fever, I wish to make one or two criticisms of the paper by Captain A. T. Nankivell and Captain C. E. Sundell in your columns, containing their observations of spirochæes in the urine in cases of this disease. In the first place I should like to ask them whether in any of their cases they have ever found spirochætes of the type which they describe in a specimen of urine collected by catheter. Again I notice that in only one of their positive cases was the smegma examined for spirochætes, none being found. I have not seen, nor bave I met anyone who has seen, this type of spirochæte in a catheter specimen of urine. On the other hand, in a case of my own-a recruit who 